\section{PRIZE ESSAY.}

Essay on the Patent Laws, IVITH SUGGESTIONS OF ALTERATIONS A
ADDITIONS FOR THEIR IMPROVEMENT.

By Edmund Maher, Civil and Mechanical Engineer, Washington, D. C.

No branch of Jurisprudence, has stronger claims upon the attention of the Legislative Department of any country; tione is better founded in justice, and sound public policy, and none more intimately connected with the advancing prosperity and welfare of society than that branch known as Patent Laws. It is designed to be, and in its practical operation has been, a power universally diffused, and putting in operation a vast amount of in tellectual machiners, for the discovery and production of new and useful things to enrich production of new and useful things to enrich
and beautify the land-and it seems to be equally true, and much to be regretted, that a policy so important is not generally understood, and is not, therefore, duly appreciated. Men find no difficulty in perceiving the propriety and necessity of laws for the protection of tangible property - with this they are generally familiar, and their importance is a part of the practical experience of all. But from a want of equal familiarity with the nafrom a want of equal familiarity with the narelation to, and bearing u $\rho$ on, public and private prosperity, they find more difficulty in comprehending, and less inclination to acknowledge the true magnitude of the policy involved, in the laws for the security of property, consisting of combinations of thoughts. That laws protecting and encouraging in. ventions are founded in pure justice, and calculated to arouse the productive energies of genius, more for the benefit of society generally, than for the benefit of the inventor, is
obvious to any one who will notice the true obvious to any one who will notice the true relation which the inventor holds to the government, and the extent to which society has already availed itself of the prodcuts of his skill.

Patent Laws are the legitimate offspring of civilization and inteligence. They belong to an age of light and knowledge. Ignorance can neither comprehend the extent of their utility. appreciate their importance,

ted to sanction their existence.

They are designed to prescribe, and establish, the relation of the invertor to the putlic, in fixing and determining their respective legal rights to the invention. They establish a relation in the nature of a mutual undersfonding, between the inventor and his governinent-the one being in consideration of the inent-

'To properly appreciate the strength of the inventor's clerims to adequate protection of law, the true nature of this understanding should be nóticed. The inventor on his part actually has something in his possession which the public is destitute of. He has practically created it, and has it in his own possession, by his allegiance to the sovereignty, on any principle of patriotism, to surrender it ; and he may of right disclose it, or not, as he pleahe may of right disclose it, or not, as he plea-
ses. He has of his own will and labor form. ed the combination of thoughts constituting the invention, and which are only to be embodied by mechanism, or mechanical action, to render it of great value. If he retain it, it will die with hum, and the world will still remain without the advantages of it. But if he divulge it, the public will be enriched, the country honored, and mankind at large re ceive the benefit. $d t$ this point the public through the instrumentality of the Patent laws, propose an arrangement to secure the disclosure, and consequent benefit of his own in vention. And what arrangement do they propuse, and what does it offer as a consideration for this new and useful thing? Does it offer anything special-anything extraordinary ?o, far from it. He is offered barely protec tion in the right to use his own article, as his own property, for the term of fourteen years, and on condition that he will then surrende
it to the public for the benetit of the world. It is obvious, therefore, that the relative right of the inventor and the public, established by the operation of the Patent Laws, is such as $\mid$ tors themselves-they seek for it from the Common Law, lacking the knowledge essen. to make it greatly for the benefit of the latter. Commissioner, and subordinate officers, of the tial to the proper decision of a question in The inventor is the party who adds some- Patent Office, who, being naturally desirous either of those branches of the arts. thing more to what previously existed; who of possessing as much controlling influence, has something of value to dispose of, which as they can, are apt to recommend the enactsociety has not. He imparts, and the public ment of laws, augmenting their powers, and receives. He comes forth in his application making the duties of their offices as congenial

receives. He comes forth in his application
for a patent, ladened with the rich fruits of
to their tastes and desires, as their comforts his a patent, ladened with the rich fruits of his genius, the accumulation, perhaps, of ma-
ny years of toil and deprivation, and makes a ny years of toil and deprivation, and makes a
donation of it to the public, reserving to him. self only, the right to it for fourteen yearsand how small is this reservation, in comparion with what he confers upon society? He vention with a profit for this limited time, while society is to have the benefit, for all While society is to have the benefit, for al
time to come Hcw would the country retime to come Hcw would the country re-
sound with eulogistic applause, if like liberality were displayed by a citizen, in making the public a like donation of lands, and mo ney, accumulated by his own industry ?

In view then of this relation between the inventor and the public, so beneficial to the priety of affording adequate protection to him for the limited time specified; and should it not be the pride, and to the honor of every intelligent citizen, and every legislator, to tax intelligent citizen, and every legislator, to tax
his attention, and contribute his infuence, in his attention, and contribute his influence, in
securing such protection. The more effectual this protection can be made, the greater will be the encouragement to the exercise of skill, and consequently the greater will be of wealth and improvement. And source measure the magnitude of such advantages ? Who can carry his thoughts far enough back to find the period in which were performed their daily routine, without the productions o inventive genius? Who can so far divest himself of the refinement, and habits, engendered by the developements of genius, as to imagine himself in that state of helpless barba. rism, from which his race has been raised, chiefly by
tor's skill.

In the organization of the several Departments of our government, and the framing of laws for the proper carrying out of the trusts
reposed in their several officers, the Legislareposed in their several offlcers. the Legisla-
tive branch of our country, has been sadly at fault, in overlooking to a comparative great extent, until within a few years past, the government, and not providing a suitable code of Laws, which shall at once protect them in the results of their genius and toil, brought about in many cases at the expense of long and anxious study, bodily health, and costly experment, and have the effect to encourage,
and stimulate invention, in the mechanic arts and develope improvements in the variou degrees and occupations of life, to keep pace with the co-extensive elements of civilization. festation on the part of Congress, their laws, of a sympathy with inventors, “ and a desire to encourage their exertions, and " otherwise assist them to the extent of their power, in the development of improvements in arts, manufactures and sciance, and these
objects can be attained, only by the passage of objects can be attained, only by the passage of laws, affording a full governmental protection by Patent to the conceptions of Inventors, in
the forms of new and useful mechanical constructions, combinations or arrangements, or other patentable differences, either of a mechanical, or chemical nature,-defining in shall constitute a patentable subject ; and hall constitute a patentable subject ; and
otherwise facilitate the progress of the useful arts, by discriminations in the selection of of -
ficers, to interpret and carry out the Laws, in ccordance with their design.

The neglect of Congress to provide suitable laws for this purpose, has not arisen wholly from a non-appreciation on their part, of the important services rendered by Inventors, to-
ward the mass of mankind, economy in the domestic affairs of the nation, and the other beneficial effects produced by the results of
their thoughts, but is mainly attributable to ig. neir thoughts, but is mainly attributable to ig. inventor, who may have wasted years of his life, in perfecting a valuable invention, is subsubject, from the proper source,-the invenmay suggest.

The mere fact of the passage of a law, by a Legislative body, for the avowed protection of an inventor's interest in an invention or disco. that it, and all the benefits accruing there from, is his property, by as strong a right, as any other description of property is held, notwithstanding that law may fail, in fully accomplishing the object for which it was deof such failure, to pass a law, giving the projector of the invention, the same right of
possession, and power of disposal, as is enpossession, and power of disposal, as is enoyed by the owners of other acknowledged which he can obtain legal authority to hold, and possess, this result of his thought as property, subject to the same restrictions and retraints, as other property, with as sligh of the proceeding will admit of

In view of this right, and with a laudable desire to render all necessary protection to in gress enacted a code of Patent Laws in 1836, repealing all other laws on the subject, in existence previous to that date, and subsequent$\mathrm{y}$, at different periods, viz. 1837, '39, '42 and 48 , passed additional Bills, for the further protection and encouragement of Inventions in the useful arts, and in a manner amendatory of the laws passed at previous dates. It is to these laws, forming when combined, the compact or code, for the guidance of the Inventor, and the conferment of an exclusive privilege to him, in the invention or discove, having an origination from himself, that turn my attention, and shall in my examination, take the several sections containing obctionable features and deficiencies, in the orer in which the y are arranged, except where wo sections, in a manner relevant to each
other, are situated out of the regular order of ther, are situated out
numerical progression.

The 6 th section of the law of 1836 , provides-" That any person or persons having discovered or invented any new and useful of matter, or any new and useful improveof matter, or any new and useful improve-
ment on any art, machine, manufacture, or composition of matter, not known or used "by others before his or their discovery or "invention thereot, and not at the time of hi “ application for a patent, in public use or on sale with his consent or allowance, as the obtain an exclusive property therein make application in writing to the Commis"sioner of Patents expressing such desire, " and the Commissioner on due proceeding " had, may grant a patent therefor."

This clause is indefinite, inasmuch as it does not define with sufficient clearness, what orms a patentable subject, but leaves the diswith the Commissioner of Patents, ostensibly, not from the multifarious duties of his office, have time to examine one case out of fifty, but in fact, with the Board of Examiners, who nderthe powers granted them in the succeeding 7 section of the law, of the sam date, on the ground that one invention, (tho' possessing advantages over another, and of course different in some particular, to pro-
duce such a result, ) is substantially the same as the first; or because of a difference of opinion with the inventor on the question as to whether it really is an improvement on the original, reject the application for a patent for the difference forming the alleged improvenot satisfied with the decision, to appeal to the Chief Justice of the District Court in Washington, to decide the question betwee the respective parties at issue, which proper-
ly belongs to the mechanic arts, or chemistry, and should be left to those skilled in the art to which it appertains, and not to a Judge of igned, and it is the duty of that body, incase ventors, in the offspring of their genius, Con

(To be Continued.)

\section{LITERARY Y NTICES.}

Autoblography of henry c. Wright. This is a neat volume of 414 pages by the
author of a Child, a Youth, a Man-the biography of Mr. Wright by himself. It is sold
by Fowler $\&$ Wells, the well known publighers in Nassau st. this city. In looking over
ents the pages of this work-reading a chapter here and a chapter there, one thing struck us must have a beautiful mind. This is our opinion, although in some things our ideas arr man can read without being benefitted.

The " Portland Transcript," a very excellent literary Journal, commences the 13 th vo-
lume with a new dress, and makes an excellent appearance. The Transcript is very ably edited, and we regard it as one of our mos
interesting exchanges. We wish the propritors success.

The May number of the Ladies National Magazine, has been sent us by the Publisher, ments are "Coming from the Bath," which is May" and "May Day in olden times" together with the usual variety of interesting matter by such popular authors as Mrs. Stevens, Mrs.
Moreton, Mr. Peterson and Mr. Shelton. The Proprietors promise excellent serial Plates for
July. Terms $\$ 2,00$. Dewitt \& Davenport,
Agents, N. Y.

Sartain's Union for May is a superb number. It contains a splendid mezzotint, by and Boaz, also " Tre Dove," by Rice, "Na.
areth," by Devereaux, " Dan Tucker in zareth," by Devereaux, " Dan Tucker in Love," "A Tournament in Utopia," besides
several others of sterling merit The literary contents are varied and interesting. Among
he contributions we notice a capital article entitled 'English Characteristics,' from the pen 